\title{
CAREER EDUCATION IN A GENERAL EDUCATION SCHOOL: CAREER EXPECTATIONS OF SENIOR FORM PUPILS
}

\author{
Violeta Jegelevičienè \\ Mykolas Romeris University, Lithuania \\ Odeta Merfeldaitè \\ Mykolas Romeris University, Lithuania \\ Asta Railienè \\ Mykolas Romeris University, Lithuania
}

\begin{abstract}
Career education is to be analysed as the factor of lifelong learning which promotes engagement, the adaption of labour force to the conditions of the market, entrepreneurship. It is the process of the acquisition and development of career competences which enables a person to manage his career. appropriate career choices, which have been made, have a great influence over person's successful socialisation. Career expectations, their analysis is a part of career planning which is oriented towards the formation of short-term and long-term career objectives. The article analyses the career expectations of senior pupils in the context of career education. The analysis of the theoretical concept of career expectations in the context of career education is presented and the analysis of the results of the quantitative study, which reveals career expectations of senior pupils, is introduced. The results of the study reveal the approach of senior pupils to their career and career expectations. The analysis of the study findings revealed that: senior pupils perceive a career in the context of contemporary career concept: as self-realisation, personal development, the sequence of learning and work experiences during life; after leaving school, further studies in the institutions of higher education are still the most popular choice; an extremely important factor of a good job and a successful career is also the reconciliation of hobbies and a job, and an opportunity to get engaged in an activity they enjoy; the respondents have career expectations not only with regard to personal development and honest assessment, but also working environment.
\end{abstract}

Keywords: career, career education, career expectations.

\section{Introduction}

One of the most important aspirations of Lithuanian education is to assist a person and society in responding to the basic challenges of today and tomorrow, in benefiting to the fullest possible extent from the opportunities that are arising. Under the conditions of a knowledge-based society, every person has to learn to adapt to changes in the market, to model a career that is individual and consistent with the needs of society. In the 21 st century a successful personal 
career is defined by the ability for a lifelong learning, to react to the changes in society and the labour market and to adapt to them. Hence, a necessity for career education is derived from a changing world and a personal need to take repeated decisions which are linked to learning or work. The provisions of the National Strategy of Education for the Years 2013-2022 stress that education has to react to changes in the labour market in a more operative way, to assist people in getting oriented, identifying their strengths and using them when searching for a job, being able to autonomously manage their career, choosing more promising directions for a career, setting up a business and his workplace independently. Strategic documents have been prepared and adopted: the European Council Resolution on lifelong guidance (2007), the National Lisbon Strategy Implementation Programme (2005), the Description of the Provision of Vocational Guidance Services (2012) underline a necessity to direct the services for career education in such a way that they would contribute to lifelong learning and the development of career competences. Career education has to be regarded as a component of educational assistance and part of the content of general education. It is the process of the acquisition and expansion of career competences which enables to manage career changes. An appropriate choice of a career has a considerable impact on a successful socialisation for a person. The choice of a career path has to be treated as a two-way interaction between an active personality and an ever-changing environment. It must be stressed that education career services is an integral part of all the educational system: the purpose of a person for education career has to be consistent with the purposes of general education; career competences that have to be developed have to be consistent with general competences; it is necessary to ensure interaction between education career and other services of educational assistance. Career expectations are a realistic self-assessment and management of an individual's career, looking to the future and the self-assessment of the future decisions regarding career management. The implementation of career expectations depends directly on the fact how an individual will be prepared to manage his career. Career management is personal and career decisions which an individual is able to take autonomously, taking into consideration competences, education and personal possibilities he currently possesses. This process encompasses the ability to adapt to the changing requirements of an activity and combine personal life and career (Domene et al., 2011; Lent et al., 1984; Kattenbach et al., 2011; Maxwell et al., 2010; Petkevičiūtè, 2006 et al.). The studies (Rogers, Creed, 2000; Sinclair, Carlsson, Björklund, 2014; Schuette, Ponton, Charlton, 2012; Thompson, Dahlin, 2010; Kattenbach, Lucke, Schlese, Schramm, 2010; Ramanauskaite et al., 2004; Pukelis, 2012; Kalinauskaitè et al., 2005; Garniené, 2006; Ustinavičiūtè et al., 2011; Meijers, Kuijpers, Gundy, 2012; Howard et al., 2011) reveal that, in senior forms, pupils have often not made their minds up 
regarding their future career, their motivation to learn is weak, they have no orientation regarding professions and the specifics of a professional activity, and the decisive criterion regarding career choice is the prestige of an educational training institution and/or a profession itself in society. The determination of a pupil regarding career intentions is aggravated by the spontaneousness of career education services in Lithuanian schools (Railienè, Gudžinskienè, 2012; Railienė, 2011, 2010; Railienè, Žadeikaitė, 2008, 2009, 2010; Indrašienè, Grinytè, 2007).

Theobject of the study is pupils' career expectations

The purpose of the study: to examine career expectations of the pupils of senior forms.

The methods of the study. 1) the analysis and summary of literature; 2) quantitative research.

Research methodology. Quantitative study was carried out by using the method of questionnairing survey. A representative sample for the study was formed. The study aimed at representing all the general education schools from all the counties of Lithuania. In order to ensure the representativeness of the sample, the sample was formed using the principle of cluster sampling. The sample size was established with $95 \%$ accuracy. The sample of the study is 282 pupils of 11th-12th forms from the gymnasiums of five different regions in Lithuania. $163(58 \%)$ girls and $119(42 \%)$ boys participated in the study. The study was conducted in the January-March of 2015. The pupils were interviewed in cooperation with the career coordinators of gymnasiums. The career coordinators of the schools, which participated in the study, responded to the invitation to participate in the study and were interested in receiving the findings of the study which would assist in developing their further activity of career education in their school. The opportunity to interview pupils was coordinated with the head teachers of schools. The data were processed using SPSS 18 (Satistical Package for Social Sciences) program package. The data were analysed while applying the method of descriptive statistics (i.e. data grouping, the calculation of frequencies, the characteristics of distributions, graphical representation of data). When analysing the parameters of statistical significance multidimensional statistics (correlation analysis; in order to highlight statistically significant differences, the data, the significance level of which is $\mathrm{p}<0,05$, will be analysed) was applied.

\section{The Concept of Career Expectations in the Context of Career Education}

EU strategic documents underline the importance of the accessibility of career education as assistance to a person to choose career in compliance with his personal abilities and interests, career education is identified as one of the 
key elements of assistance, in order to increase employment powers of an individual, his competitiveness on the labour market. In the context of the interaction between education and labour market and the increase of the accessibility of lifelong learning, career education is defined as one of the most important elements when creating open, attractive and accessible learning environment in order to support learning during various age periods and in a variety of environments, to empower citizens to manage their learning and career. Career education is identified as one of the factors which promote lifelong learning, employment, the adaption of workforce to the conditions of labour market and entrepreneurship (Lisbon Declaration, 2000; Copenhagen Declaration, 2002; Education and Training 2010).

Contemporary career concept, ever-changing economic and labour market situation inspires educational bodies to review the services of career education in schools as well. If the purpose of career education has previously been identified as the pupil's ability to respond to the question "What will you be when you grow up?", that is not sufficient in today's situation. The development of career competencies, which empower the pupil to know, create and achieve self-realization in an ever-changing world, is becoming a prime objective for career education in the school. Career education should be regarded combined and systematic efforts of educational institutions, parents and community in linking education and work while assisting individuals to acquire and use attitudes, knowledge and skills, in order that work would be a meaningful, productive and fulfilling part of every individual's life. It is the empowerment of an educatee to manage the changes of personal and professional career (Harris, 1999; Guichard, 2001; Kučinskienè, 2003; Pukelis, 2003; Garnienè, 2006). In a broad sense,career education should be defined as a focused process of the acquisition and development of career competencies on the basis of an interaction which is being created. Career competences are many of the skills and personal qualities which are necessary for a person in the contemporary world of employment and that he can successfully apply in a practical activity (Stanišauskienè, 2005; Sokolova \& Stanišauskienè, 2007). At school, selfassessment and self-reflection skills, which empower to review acquired skills, knowledge, the set up learning objectives and not to be afraid to carry out their self-assessment and change them, have to be developed in pupils (Augustiniene et al., 2006). In the process of career education, an individual should be treated as an active participant of this process, and not as passive recipient of the service, i.e. the services of career education aimed at assisting people in creating and managing their career by themselves (Bailey, 2006; Kattenbach et al., 2011; Maxwell et al., 2010). Hence, career education is necessary at school due to the fact that not only does it allow to adapt to extremely rapidly changing working 
and economic environment, but also empowers individuals to react to failures in a more flexible way and ensures a more successful management of their career.

In the process of career education, career expectations is a realistic looking forward of an individual and the self-assessment of his future career choices. Career expectations show individual's priorities of career management and are directly linked to career mobility. Career expectations are the expected results of a certain taken action (Domene et al., 2011; Lent et al., 1984). Career expectations have a direct impact on the engagement of individuals in a certain activity, they encompass a few areas - promotions, conditions, courses of action (Guthrie, 2009), salary, guaranteed place of employment, opportunities for development, work in a positive environment, the fulfillment of personal goals, reasonable managers, to have a guaranteed future (Maxwell et al., 2010). Career expectations are also characterised as the anticipation of self-realisation, including professional one, which is focused on the future. A person, who has expectations, believes in a successful directing of his activity to achieve an expected result. Expectation and motivation are strongly interlinked: a better learning now will guarantee greater success in the future (Uzdila \& Zujiené, 2007; Urbanavičiūte, 2008). Both external (economic situation, its change, developments on the labour market, changes in the organisation) and internal (individual's character; learning situation and education, close environment) factors have impact on the formation of career expectations (Kattenbach et al., 2011).

The studies over the last decade have revealed that pupils in senior forms have often not made their minds up regarding their career ambitions (Rogers, Creed, 2000; Ramanauskaite et al., 2004; Pukelis, 2012; Kalinauskaite et al., 2005; Garnienè, 2006; Ustinavičiūtè et al., 2011; Meijers et al., 2012), their career expectations are linked to the aspiration to study in the institution of higher education, to have a well-paid job, to achieve self-realisation (Sinclair et al., 2014; Lamanauskas et al., 2013; Schuette et al., 2012; Thompson \& Dahlin, 2010; Kattenbac et al., 2010; Howard et al., 2011).

\section{Career expectations among Senior Pupils: the Analysis of the Findings of the Study}

The purpose of the study was to examine how the respondents understand their career (Table 1). The analysis of the findings of the study revealed that contemporary career concept is the most popular among the respondents: $58 \%$ of girls and $57 \%$ of boys construe a career as the sequence of lifelong learning and work experiences; $62 \%$ of girls and $43 \%$ of boys think that a career is a personal development. $53 \%$ of girls and $41 \%$ of boys link a career to achieving self-realisation. The findings spread almost evenly, however, slightly more girls 
orient their career towards personal development, whereas boys allocate more attention to positions they would like to hold and salary.

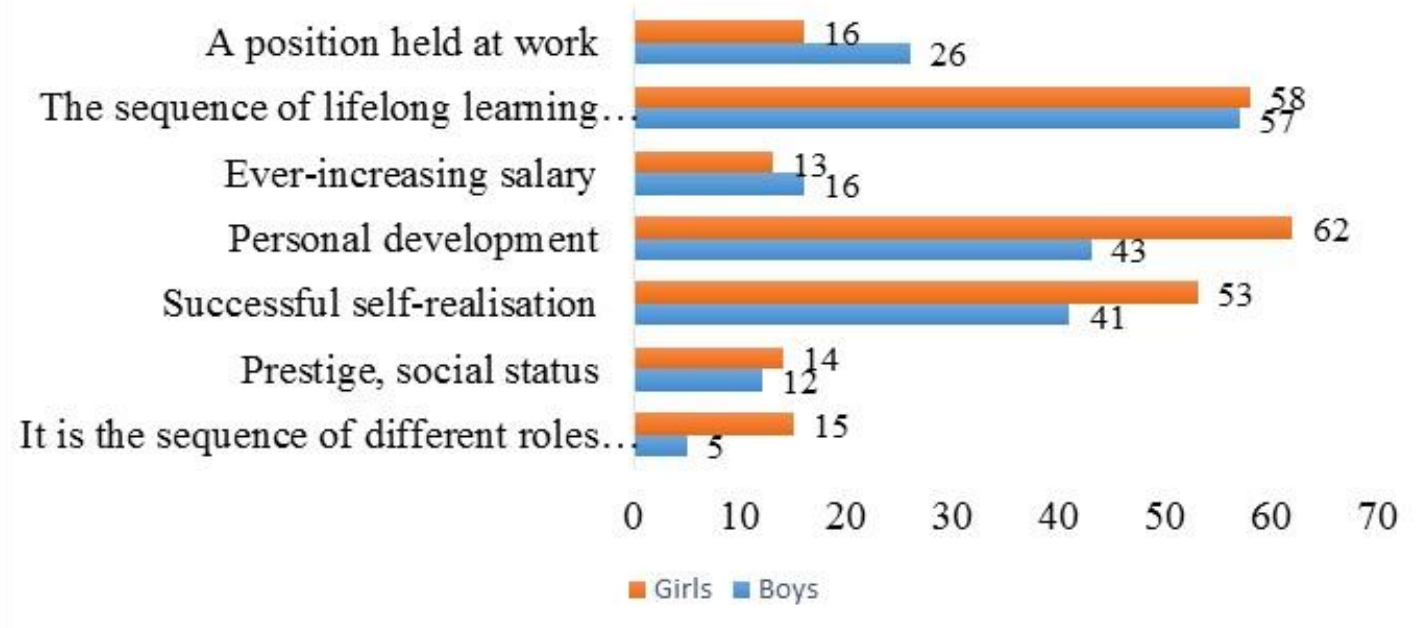

Table 1 The opinion of the respondents regarding what career is (percentages)

11th -12 th form pupils have already to make their first decisions related to the realisation of their career objectives by constructing their individual development plan and choosing subjects. Hence, the purpose of the study was to examine what respondents' plans after completing school were.

It was established that $81 \%$ of girls intend to study in Lithuanian institutions of higher education, $14 \%$ - in foreign. Whereas $75 \%$ of boys choose their further studies in Lithuania, $16 \%$ of them - abroad. Boys choose to learn in vocational training schools slightly more often. Only a small part of the respondents indent to begin working after completing their school (4\% of boys and fewer than $1 \%$ of girls). The findings of the study reflect the general situation in Lithuania. According to the data of the Ministry of Education and Science (2009), the majority of the students, who study in the institutions of higher education, are girls, whereas the majority of the students in vocational training schools are boys. The latter choose to start working after completing their school more often, but not further studies.

In order to establish career expectations of the respondents, the following characteristics of career expectations were assessed: promotion, working conditions, action lines, salary, job security and stability, working environment, development opportunities, future perspectives, personal satisfaction, relationships with a manager (Kattenbach et al., 2011; Maxwell et al., 2010; Urbanavičiūtè, 2008; Lamanauskas et al., 2013). The analysis of the findings of the study revealed that more than half of the respondents $(60 \%)$ link career to an opportunity to pursue an activity which they enjoy. Slightly more boys than girls (54\% of boys, $42 \%$ of girls) link their career expectations to an 
opportunity to combine work with hobbies. Only a slight difference is observed in linking career expectations to hierarchical rising in a position ( $43 \%$ of boys, $37 \%$ of girls) (see Table 2).

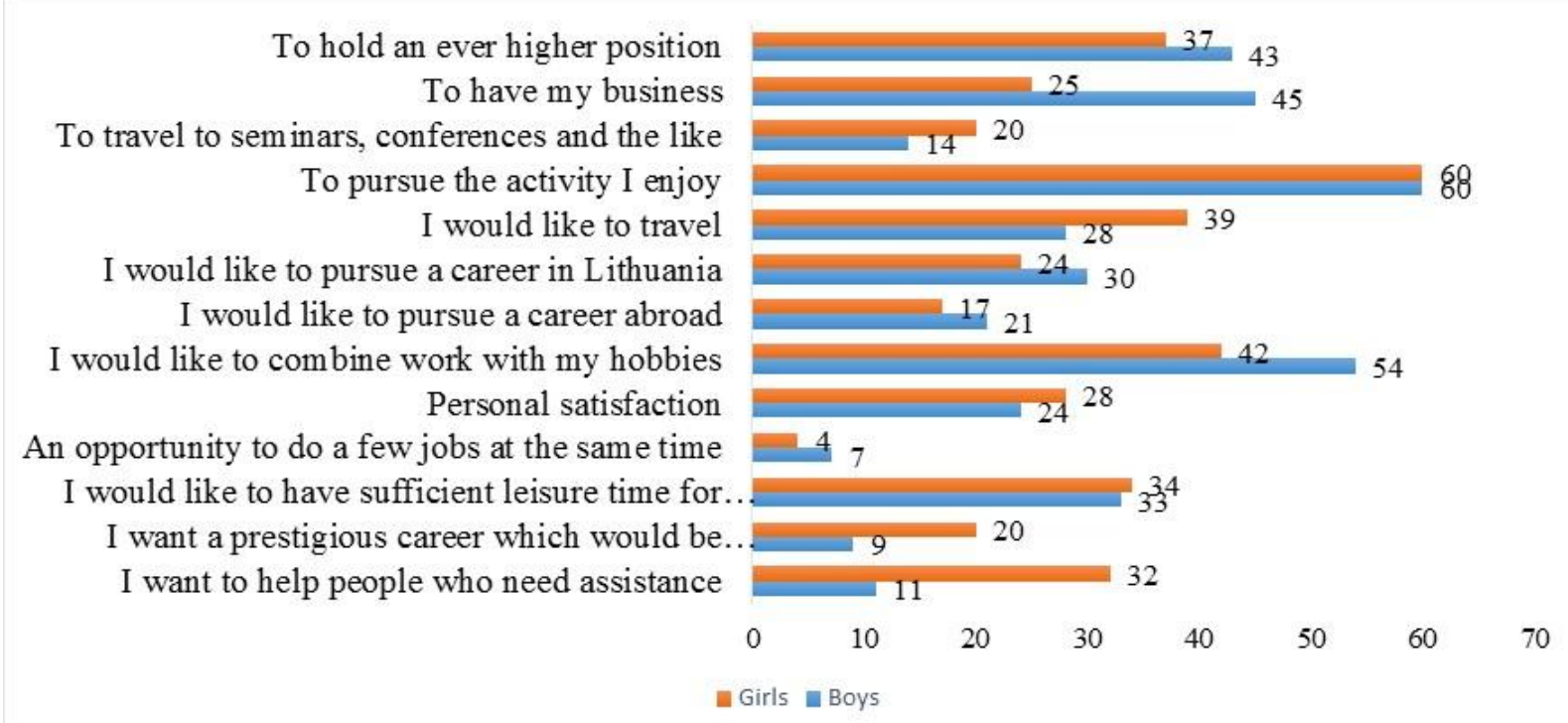

Table 2 Career expectations of the respondents (percentages)

Both girls and boys assess many of their expectations similarly: aspiration for personal satisfaction ( $28 \%$ of girls, $24 \%$ of boys), an opportunity to travel (39 \% of girls, $28 \%$ of boys), development opportunities, i.e. seminars, conferencies and the like (20\% of girls, $14 \%$ of boys), the combination of a few jobs at the same time (7\% of boys and $4 \%$ of girls). $30 \%$ of male respondents and $24 \%$ of girls intend to pursue their career in Lithuania, whereas $21 \%$ of boys bei $17 \%$ of girls intend to do it abroad (see Table 2).

When analysing the findings of the study it was established that there is a very considerable divergence of opinions between respondents-girls and respondents-boys when assessing the links of personal career to assistance to people. $32 \%$ of girls and only $11 \%$ of boys would like to link their career to an activity which provides assistance to people $(\mathrm{p}=0.01 ; \mathrm{p}<0.05)$. A statistically significant difference was also determined in respondents ${ }^{6}$ opinions regarding career links to a private business. $45 \%$ of boys and $20 \%$ of girls $(\mathrm{p}=0.03$; $\mathrm{p}<0.05$ ) would like to have their own business. It confirms the statements, which are prevalent in the scientific literature (Fortin, 2005; Ashby \& Schoon, 2010; Correll, 2004), that girls choose activities, which are linked to assistance to others, more often than boys, they are more inclined towards altruistic pursuits, boys choose activities, which have greater prestige, more often. The findings of the study show that the respondents link their career to the activity, which 
provides self-realisation and personal satisfaction, and an opportunity to be objectively valued when rising up the career ladder.

\section{Outcomes and conclusions}

Career education is a systematic and focused process, the individual's system of the acquisition of integral knowledge, skills, abilities and attitudes towards self and the world of work and the behaviour in it, the basis of which is the development of career competences which empower an individual to continuously design their professional career in the context of constant changes on the labour market. The purpose of career education is to empower an individual to manage his personal, academic and professional career. Career expectations show individual's career priorities and are directly linked to decision making regarding his career. They motivate an individual to learn and attain his objectives.

The analysis of the study findings revealed that:

- $\quad$ senior pupils perceive a career in the context of contemporary career concept: as self-realisation, personal development, the sequence of learning and work experiences during life.

- after leaving school, further studies in the institutions of higher education are still the most popular choice. The key factors of such choice are a desire to acquire higher education qualifications and a profession.

- for respondents, an extremely important factor of a good job and a successful career is also the reconciliation of hobbies and a job, and an opportunity to get engaged in an activity they enjoy, however, a significantly larger number of girls than boys link their career with an aspiration to help people.

- the respondents have career expectations not only with regard to personal development and honest assessment, but also working environment. It is extremely important for pupils to work in a friendly environment and maintain harmonious relationships with a manager.

\section{References}

Ashby, J. S., \& Schoon, I. (2010). Career success: The role of teenage career aspirations, ambition value and gender in predicting adult social status and earnings. Journal of Vocational Behaviour, 77, 350-360.

Augustinienè, A., Čiučiulkienè, N., Čiužas, R., \& Šiaučiukènienė, L. (2006). Mokinių gebėjimu priimti karjros sprendimus ugdymo dalyviai kaip besimokanti bendruomenė.

Pedagogika, 84, 93-100.

Bailey, M. A. (2006). Finding the right career path. WetFeet: San Francisco. 
Cochran, D. B., Wang, E. W., Stevenson, S. J., Johnson, L. E., \& Crews, Ch. (2011). Adolescent Occupational Aspirations: Test of Gottfredson's Theory of Circumscription and Compromise. The Career Development Quarterly, 59 (5), 412-427.

Correll, S. J. (2004). Constraints into Preferences: Gender, Status, and Emerging Career Aspirations. American Sociological Review. 69, 93-113.

Domene, J. F., Socholotiuk, K. D., \& Woitowocz, L. A. (2011). Academic motivation in postsecondary students: Effects of career outcome expectations and type of aspiration. Canadian Journal of Education, 34 (1), 99-127.

Ferry, N. M. (2006). Factors Influencing Career Choices of Adolescents and Young Adults in Rural Pennsylvania. Research in Brief, 44 (3). Downloaded from: http://www.joe.org/ joe/ 2006june/index.php.

Fortin, N. M. (2005). Gender role attitudes and the labour-market outcomes of women across OECD countries. Oxford Review of Economic Policy. 21 (3), 416-438.

Garnienè, D. (2006). Model of career education at general education school: Parameters and realisation principles. Summary of doctoral dissertation. Kaunas: Vytauto Didžiojo universiteto leidykla.

Garnienè, D. (2006). Model of career education at general education school: parameters and realisation principles Bendrojo lavinimo mokyklos ugdymo karjerai modelis: parametrai ir realizavimo principai: summary of doctoral dissertation. Kaunas: Vytauto Didžiojo universiteto leidykla.

Gudžinskienè, V., \& Railienè, A. (2012). The interface between life skills and career education: The aspect of secondary education. Acta paedagogica Vilnensia: academic papers, 29, 61-72.

Guichard, J. (2001). A century of Career Education: Review and Perspectives. International Journal fo Educational and Vocational Guidance, 1, 155-176.

Guthrie, L. (2009). The Next Generation of Workers. The Ken Blanchard Companies.

Harris, S. (1999). Careers Education. Contesting Policy and Practice. London: Paul Chapman Publishing Ltd.

Howard, K. A. S., Carlstrom, A. H., Katz, A. D., Chew, A. Y., Ray, G. C., Laine, L., \& Caulum, D. (2011). Career aspirations of youth: Untangling race/ethnicity, SES, and gender. Journal of Vocational Behaviour, 79, 98-109.

Indrašienė, V., \& Grinytè, L. (2007). Tèvų požiūris ì profesinį orientavimą bendrojo lavinimo mokykloje. Pedagogika, 87, 119-125.

Kalinauskaite, R., Adaškevičienè, V., Tarnauskas, K., \& Žvirdauskas, D. (2005). Pasirinktu studiju ir mokykloje pasirinkto ugdymo turinio derme: Mokslinio tyrimo ataskaita. Kaunas: Vytauto Didžiojo universitetas. Downloaded from http://www.smm.lt/ svietimo_bukle/docs/tyrimai/Ugdymo_turinio_dermes_atask_.doc.

Kattenbach, R., Lucke, J., Schlese, M., \& Schramm, F. (2011). Same but Different Changing Career Expectations in Germany? Zeitschrift für Personalforschung, 25 (4), 292-312.

Kučinskienè, R. (2003). Ugdymo karjerai metodologija. Klaipėda: Klaipėdos universiteto leidykla.

Lamanauskas, V., Augienė, D., \& Makarskaitė - Petkevičienė R. (2013). Universitetiniu studiju problematika, 1 (13), 8-18.

Lent, R. W., Brown, S. D., \& Hacket, G. (2002). Social Cognitive Career Theory. In Brown, D. \& Associate (Eds.). Career Choice and Development. San Francisko: Jossey - Bass, 255-314. 
Lent, R. W., Lopez, A. M., Lopez, F. G., \& Sheu, H. B. (2008). Social cognitive career theory and the prediction of interests and choice goals in the computing disciplines. Journal of Vocational Behavior, 73, 52-62.

Leung, S. A. (2008). International Handbook of Career Guidance. Netherlands: Springer Netherlands.

Leung, S. A., Zhou, S., Ho , E. Y. F., Li, X., Ho, K. P., \& Tracey, T. J. G. (2014). The use of interest and competence scores to predict educational choices of Chinese high school students. Journal of Vocational Behavior, 84, 385-394.

Meijers, F., Kuijpers, M., \& Gundy, C. (2013). The relationship between career competencies, career identity, motivation and quality of choice. International Journal for Educational and Vocational Guidance, 13 (1), 47-66.

Patton, W. A., \& McMahon, M. L. (2014). Career Development and Systems Theory. Rotterdam: Sense Publishers.

Petkevičiūtè, N. (2006). Karjeros valdymas: asmeninè, individualioji perspektyva. Kaunas: Vytauto Didžiojo universitetas.

Pukelis, K. (2003). Karjeros projektavimo gebėjimai žinių visuomenèje: nauji iššūkiai profesiniam konsultavimui ir karjeros planavimui. Profesinis rengimas: tyrimai ir aktualijos, 6, 66-75.

Pukelis, K. (2012). Karjeros projektavimas: kodèl ir kas? Karjeros projektavimas: tyrimai ir konsultavimas, 1, 12-45.

Railienè, A. (2007). Mokinių požiūris i profesinio informavimo organizavimą bendrojo lavinimo mokykloje. Pedagogika, 88, 50-57.

Railienè, A. (2010). Development of Professional Advisor's Competences in Social Pedagogues Teaching: Summary of Doctoral Dissertation. Vilnius: Vilnius Pedagogical University.

Railienè, A. (2011). Profesijos patarejo veiklos profesinio orientavimo sistemoje prielaidos. Socialinis darbas: Mokslo darbai, 10 (2), 157-168.

Railienè, A., \& Gudžinskienè, V. (2012). Development of social skills and career competences in child day-care centres: Attitude of day-care centre specialists. Social work: Academic papers, 11 (1), 85-96.

Ramanauskaitè, A., Laužackas, R., Targamadzè, V., Indrašienè, V., Statauskienė, L., \&, Bukantaitè, D. (2004). 14-19 metu paaugliu, linkusiu i praktine veikla, mokymosi krypties pasirinkimo galimybes: Tyrimo ataskaita. Downloaded from www.smm.lt/svietimo_bukle/docs/Ataskaita_baig.doc.

Rogers, M., \& Creed, P. (2000). School-To-Work Transition: From Theory to Practice. Downloaded from http://adapt.it/adapt-indice-a-z/wp-content/uploads/2014/ 04/STWT_Theory_Practice.pdf.

Schuette, C. T., Ponton, M. K., \& Charlton, M. L. (2012). Middle school children's career aspirations: relationaship to adult occupations and gender. The Career Development Quarterly, 60, 36-46.

Sinclair, S., Carlsson, R., \& Björklund, F. (2014). The role of friends in career compromise: Same-gender friendship intensifies gender differences in educational choice. Journal of Vocational Behavior, 84 (2),109-118.

Sokolova, A., \& Stanišauskienè, V. (2007). Profesinio orientavimo sistemos Lietuvoje teorinès ir politinès prielaidos. Profesinis rengimas: tyrimai ir realijos, 13, 226-241.

Stancikienè, A. (2009). Teoriniai profesinès karjeros valdymo aspektai. Viešoji politika ir administravimas, 29, 107-113. 
Stanišauskienè, V. (2005). The Model of Career Competence and its Expression in the Contemporary Labour World. Learning and Development for innovation, networking and Cohesion, 89-105.

Stanišauskienė, V., \& Večkienė, N. (2000). Rengimasis karjerai socialinių transformacijų laikotarpiu: Lietuvos gimnazijose egzistuojančiu prielaidų analizè. Socialiniai mokslai, 1 (22), 85-97.

Svarbiausi Bolonijos proceso dokumentai. Bolonijos-Londono laikotarpis 1999-2007 m. (2008). Vilnius: Śvietimo aprūpinimo centras.

Teresevičienè, M., \& Ivoškaitè, M. (2008). Mokinių karjeros kompetencijos plètojimas profesinejje mokykloje vertinant mokymosi pasiekimus. Mokytoju ugdymas, 10, 39-56.

Thompson, M. N., \& Dahling, J. J. (2010). Image theory and career aspirations: Indirect and interactive effects of status-related variables. Journal of Vocational Behavior, 77, 21-29.

Urbanavičiūtè, I. Psichologinès studentų profesinių tikslų kèlimo prielaidos. Socialinis darbas, 7 (3), 110-118.

Ustinavičiūtè, L., Katkonienè, A., \& Žemaitytè, I. (2011). Veiksniai, susiję su sėkmingu karjeros planavimu ir profesijos pasirinkimu paauglysteje. Socialinis darbas, 10 (2), 196-180.

Uzdila, J. V., \& Zujienè, N. Pradinio ugdymo pakopos mokinių profesiniai lūkesčiai. Socialinis ugdymas, 3 (14), p. 40-50.

Valstybine švietimo 2013-2022 metu strategija. Downloaded from http://www.smm.1t/uploads/documents/VSS_2013-2022_2013-08-23.pdf.

Žadeikaite, L., \& Railienè, A. (2008). Work opportunities of a social educator within the vocational information system. Social education, 5 (16), 124-132.

Žadeikaite, L., \& Railienè, A. (2009). Functions and competencies of a social educator as a vocational adviser: theoretical assumptions. Socialinis ugdymas, 8 (19), 107-120. 